\title{
Pelarangan Pihak Asing sebagai Pemberi Sumbangan Dana Kampanye Pemilu
}

\author{
Hesti Widyaningrum
}

Fakultas Hukum, Universitas Bhayangkara Jakarta Raya

Korespondensi: hesti.widyaningrum01@gmail.com

\section{Info Artikel}

Naskah diterima : 4 Feb 2020 | Revisi : 28 Feb 2020 | Disetujui : 8 Mar 2020

\begin{abstract}
Abstrak
Penulisan ini menganalisa alasan pentingnya pelarangan pihak asing sebagai pemberi sumbangan dana kampanye Pemilu dan dampaknya. Hasilnya Peraturan yang bersebrangan antara pelarangan menerima sumbangan dana kampanye dari pihak asing dan diperbolehkannya Peserta Pemilu menerima dari perusahaan. Padahal antara perusahaan dan pihak asing saling berkaitan satu sama lain jika melibatkan Investor dan lembaga swasta asing dalam permodalan perusahaan. Pelarangan tersebut tidak menutup celah bagi pihak asing terlibat sebagai pendonor kampanye. Ditambah, tidak adanya sanksi terhadap pihak asing yang berkontribusi dalam dana kampanye, semakin membuat pihak asing lebih leluasa terlibat dalam urusan politik di Indonesia. Pasalnya Investasi Asing mendominasi permodalan di Indonesia. Otomatis, ini berpotensi terjadinya transaksi antara pihak Asing untuk mengintervensi kebijakan negara untuk kepentingannya, sebaliknya kepentingan publik terabaikan. Politik transaksional ini membuat peserta pemilu melakukan berbagai cara untuk mendulang suara seperti vote buyying. Akhirnya, Pemilu menjadi ajang jual-beli, sehingga suara pemilih hanya menjadi komoditas dalam logika ekonomi. Adanya Kekosongan hukum ini, maka perlu ditambahkannya klausul baru dalam Pasal 527 terhadap pihak asing sebagai pemberi sumbangan dana pemilu. Ini sebagai bentuk antisipasi keterlibatan pihak asing yang berkontribusi dana kampanye.
\end{abstract}

Kata kunci: Pelarangan, Pihak Asing, Dana Kampanye, Pemilu

\section{Abstract}

This writing is aimed at analyzing the reasons for the importance of banning foreign parties from the contribution of election campaign funds and their impact. As a result the contradictory regulations between prohibition of accepting campaign funds from foreign parties and the permissibility of Election Contestants receive from corporation. Whereas between companies and foreign parties are interrelated if they involve investors and foreign private institutions in the corporation's capital. The ban does not close the gap for foreign parties involved as campaign donors. In addition, the absence 
of sanctions against foreign parties contributing to campaign funds increasingly makes foreigners more involved in political affairs in Indonesia. Because Foreign Investment dominates investment in Indonesia. Automatically, this has the potential for transactions between foreign investors to intervene in state policies for their interests, otherwise the public interest is denied. Transactional politics makes election participants do various ways to gain votes such as vote buyying. This legal gap must be complete, it is necessary to add it through the addition of a new clause in Article 527 to foreign parties as donors of election funds. This is a form of anticipation from those who contribute to campaign funds.

Keywords: Prohibition, Foreign Parties, Campaign Funds, Elections

\section{PENDAHULUAN}

\section{A. Latar Belakang}

Kampanye Pemilu kerap kali diwarnai dalam berbagai kegiatan oleh Peserta Pemilu, sebagai upaya untuk mendulang suara dari Pemilih. Peserta Pemilu dapat menyampaikan visi, misi, hingga program melalui kampanye tersebut. Sayangnya, tidak semua Peserta Pemilu berlaku demikian, banyak juga Peserta Pemilu melakukan jalan pintas untuk mendapatkan dukungan oleh Pemilih melalui tindakan politik uang, seperti Vote buyying. Sebab itu, Biaya kampanye akhirnya menjadi lebih mahal meningkatkan cost menjadi lebih tinggi. ${ }^{1}$

Oleh sebab itu, Peserta Pemilu memerlukan dana dalam proses kampanye. Sumber dana ini yang kemudian dapat digunakan oleh peserta pemilu untuk kebutuhan kampanye. Peserta Pemilu dapat memperoleh dana tersebut mulai dari pribadi, perorangan, kelompok hingga sektor swasta dalam hal ini perusahaan, akan tetapi jumlah dana yang diperoleh dibatasi dalam Undang-Undang Nomor 7 tahun 2017.

Sedangkan Undang-Undang Pemilu tegas melarang Peserta pemilu untuk menerima pihak asing untuk sumbangan dana kampanye pemilu. Padahal antara perusahaan dan pihak asing dalam ekonomi saling berhubungan terkait dalam hal permodalan. Berbicara mengenai perusahaan, maka kita mengetahui bahwa perusahaan tidak semuanya berasal dari modal dalam negeri, melainkan asing.

Apalagi modal asing dari investor asing saat ini juga berperan cukup signifikan dalam roda ekonomi di Indonesia dimana sebagian Penanaman modal

\footnotetext{
${ }^{1}$ Shari Bryan and Denise Baer, Ed, (2005), Money In Politics, A Study of Party Financing Pratices in 22 Countries, USA: Library of Congress, hlm.16.
} 
yang ada di Indonesia dikuasai oleh Asing. ${ }^{2}$ Pengaturan sumbangan dana kampanye dari perusahaan akhirnya menimbulkan bias jika dihubungan dengan pelarangan dana kampanye pemilu dari pihak asing. Sayangya, Undang-Undang Pemilu sendiri tidak mengatur pelarangan pihak asing dalam memberikan sumbangan dana pemilu.

Tidak adanya pengaturan tersebut, maka menurut Penulis patut untuk dikaji kembali karena pihak asing dalam hal ini, juga memiliki peran dalam perusahaan di Indonesia melalui permodalan yang ada. Berdasarkan latar belakang ini, maka penulis ingin membahas Bagaimana pengaturan istilah pihak asing dalam pelarangan sumbangan dana kampanye pemilu? Apa potensi dampak keterlibatan pihak asing terhadap sumbangan dana kampanye pemilu dalam negara hukum Pancasila yang demokratis?

\section{B. Metode}

Pada penulisan ini menggunakan metode penelitian normatif. Pendekatan yang digunakan berupa pendekatan konseptual dan perundang-undangan. Penulisan ini menggunakan data sekunder berupa Perundang-undangan serta jurnal internasional atau nasional, makalah, buku, dan bahan hukum lainnya yang berkaitan dengan permasalahan dalam tulisan ini. Pembahasannya dianalisis secara kualitatif. Hasilnya kemudian ditarik kesimpulan secara Induktif.

\section{PEMBAHASAN}

\section{A. Ambiguitas Istilah "Pihak Asing" Dalam Pengaturan Larangan Dana Kampanye}

Kemajuan ekonomi suatu negara tidak terlepas adanya peran sektor swasta di dalamnya. ${ }^{3}$ Pendapatan negara yang tidak mencukupi kebutuhan dalam pembangunan nasional, akhirnya mendorong segala kebijakan negara untuk membuka kesempatan pihak swasta hingga investor asing dalam menanamkan modalnya di suatu negara, hal ini tak terkecuali juga dilakukan oleh pemerintah Indonesia. ${ }^{4} \mathrm{Hal}$ ini dapat kita lihat dalam berbagai paket kebijakan ekonomi dalam

\footnotetext{
2 Badan Koordinasi Penanaman Modal, Laporan Realisasi Penanaman Modal PMDN-PMA Tahun 2018

${ }^{3}$ Bombong Bintoro Soedjito, Peran Serta Swasta dalam Pembangunan Infrastruktur di Indonesia, Jurnal studi Pembangunan, Volume 1 Nomor 1 Tahun 1998, hlm. 7.

${ }^{4}$ Badan Koordinasi Penanaman Modal, Siaran Pers Dorong Percepatan Penanaman Modal, BKPM Fokus Pada Konektivitas Ekonomi, hlm. 1.
} 
masa kepemimpinan Bapak Presiden Jokowi Widodo sejak Beliau pertama kali menjabat sudah menghasilkan berbagai kebijakan yang melibatkan peran swasta didalamnya sebagai penyedia modal untuk meningkatkan industri nasional. ${ }^{5}$ Modal yang diperoleh dari pihak swasta itu sendiri berasal baik dari dalam negeri (Penanaman Modal Dalam Negeri maupun Penanaman Modal Asing). ${ }^{6}$

Sayangnya permodalan dalam negeri tidak cukup banyak dalam mendukung pembangunan ekonomi nasional hari ini. Data BPKM tahun 2018 sendiri mencatat bahwa sumber modal yang terbesar berasal dari Modal Asing sebesar 58.8\%. Peran Investasi Asing cukup signifikan dalam industri di Indonesia, sehingga secara tidak langsung perusahaan-perusahaan swasta di Indonesia berasal dari sumber asing di dalamnya. Besarnya peran pihak asing melalui investasinya dalam mendongkrak ekonomi suatu negara, bukan berarti diakui sebagai pihak yang diperbolehkan dalam berkontribusi dalam politik di Indonesia, khususnya dalam sumbangan dana kampanye. Hal ini tentunya hanya peran pihak swasta yang diakui keberadaannya untuk berpartisipasi dalam "pesta demokrasi" di Indonesia. Kontribusi Pihak swasta dalam politik di Indonesia dibenarkan dalam undang-undang hanya dalam hal memberikan sumbangan dana kampanye. Hal ini diatur dalam Undang-Undang Nomor 7 Tahun 2017 tentan Pemilu. Baik dalam kampanye pemilu Presiden dan Wakil Presiden serta Anggota DPR, DPR Provinsi, juga DPR Kabupaten/Kota.

Tetapi, kontribusi pihak swasta, atau perusahaan dalam hal ini hanya memiliki batasan yang tegas yakni hanya dapat memberikan sumbangan dana kampanya tidak melebihi 25 Milyar Rupiah sebagaimana disebutkan dalam Pasal 327 ayat 2 dan 331 ayat 2. Batasan ini juga disertai kewajiban bagi setiap partai politik peserta pemilu untuk melaporan dana kampanye yang diperoleh maupun yang dikeluarkan dalam kepentingan kampanye mereka kepada KPU. Selain pihak swasta sendiri, sumbangan dana kampanye dapat diperoleh dari pribadi peserta pemilu, Partai Politik atau gabungan partai politik yang mengusulkan peserta pemilu, suatu kelompok, perusahaan, dan atau badan usaha non pemerintah vide 325 ayat 2 dan Pasal 329 ayat 2. Sedangkan peserta pemilu sendiri dilarang menerima sumbangan dana kampanye berasal dari pihak asing, penyumbang yang tidak jelas

5 Hendra Kusuma, Daftar Lengkap Paket Kebijakan Ekonomi I hingga XIV, https://economy.okezone.com/read/2016/11/10/20/1538279/daftar-lengkap-paket-kebijakanekonomi-i-hingga-xiv, diakses tanggal 15 Agustus 2018. 
identitasnya, hasil tindak pidana, dan sebagainya yang diatur dalam Pasal 339 ayat 1 Jo. Pasal 527.

Larangan sumber dana untuk pemilu ini, khususnya, dana yang berasal dari pihak asing ini masih menimbulkan ambigu. Peraturan KPU Nomor 5 tahun 2017 Pasal 49 menjelaskan bahwa kategori pihak asing adalah:

1. Negara Asing (Foreign Government)

2. Lembaga Swasta Asing

3. Lembaga Swadaya Masyarakat Asing

4. Warga Negara Asing (Foreign Nationals)

Kategorisasi pihak asing ini seolah-olah berdiri sendiri dan tidak ada hubungannya dengan badan hukum swasta atau perusahaan yang dimaksud dalam undang-undang pemilu. Padahal perusahaan atau badan hukum swasta ini berhubungan erat dengan pihak asing jika melibatkan investor asing dalam permodalan usahanya sebagaimana diatur dalam Undang-Undang Penanaman Modal Nomor 25 Tahun 2007. Modal asing dalam bentuk Perusahaan sendiri dalam Bentuk Perseroan Terbatas Sebagaimana disebutkan dalam Pasal 5 ayat 2 . Terminologi pihak asing, dapat masuk dalam kategorisasi No. 2 dan 4 jika merujuk dalam Undang-Undang Penanaman Modal. Akan tetapi hal ini terdapat ambiguitas ketika melihat dinamika ekonomi saat ini. Seperti yang diawal pada pembahasan oleh penulis, dimana sektor swasta saat ini tak jarang melibatkan pihak asing di dalam roda ekonomi mereka melalui investasi yang ditanamkan dalam usaha-usaha perusahaan atau industri. Bahkan dalam lampiran Peraturan Presiden Nomor 44 tahun 2016 mengatur secara jelas presentasi modal saham asing dalam berbagai jenis usaha. Modal merupakan salah satu syarat penting dalam berdirinya perusahaan tersebut. Secara tidak langsung,

Akibatnya, batasan ini menimbulkan ketidakkonsistenan pemerintah dalam mencegah pihak asing melalui partisipasinya dalam politik. Konteks pelarangan pihak asing dalam undang-undang ini jelas bersebrangan dengan diperbolehkannya Badan Hukum Swasta untuk memberikan dana kampanye dalam Pemilu, karena investor asing yang juga menanamkan modalnya di dalam perusahaan-perusahaan swasta di Indonesia, secara harfiah termasuk dalam kategorisasi pihak asing. Jika melihat hal seperti ini, maka pengaturan legalnya sumbangan dana kampanye oleh perusahaan kontraproduktif dengan larangan dari pihak asing. Kondisi dituntut 
perlunya kepastian hukum dalam menegaskan keterlibatan pihak asing dalam sumbangan dana kampanye pemilu itu sendiri.

Tentunya, secara substansif terdapat celah hukum untuk pihak asing berkontribusi atau mendonasi dana kampanye melalui perusahaan yang ada di Indonesia sebagai sumber dana yang dilegalkan bagi peserta pemilu. Selain itu juga, pengaturan pembatasan sumbangan dana kampanye pemilu oleh batasan hukum swasta atau perusahaan dalam UU Pemilu, hanya terbatas pada sifat yang sangat administatif semata. Hal ini dapat dilihat konten Pasal 8 ayat 2 huruf d Peraturan KPU tersebut, mengenai kelengkapan dokumen yang harus diserahkan dalam pelaporan penerimaan sumbangan dana kampanye dari badan hukum swasta kepada KPU, seperti jumlah dana yang diperoleh, NPWP, surat-surat yang berkaitan dengan legalitas badan hukum tersebut. Sayangnya, belum ada peraturan tegas, mengenai batasan badan hukum swasta yang seperti apa yang masuk dalam kategorisasi pihak asing ini jika ternyata badan hukum swasta yang hari ini modalnya juga berasal dari modal asing dan mendominasi dalam perusahaan tersebut.

Walaupun Peraturan pelarangan ini dianggap sudah cukup "ideal” dengan adanya keberadaan Bawaslu dalam mengawasi peserta pemilu yang menerima sumbangan dari pihak asing, plus sanksi pidana bagi setiap peserta pemilu yang menerima dari pihak asing, sebagaimana yang diatur dalam Pasal 527 UndangUndang Pemilu. Menurut penulis sendiri, itu masih kurang cukup mengontrol keterlibatan pihak asing dalam dana kampanye pemilu. Selain celah hukum yang telah disebutkan di atas, juga sanksi tersebut tidak dikenai terhadap pihak asing yang memberik sumbangan tersebut.

Pelarangan pihak asing dalam dana kampanye ini bukan hanya isu baru, namun isu ini sudah ada sejak abad ke-20. Ada alasan negara-negara melarang hal tersebut, seperti Amerika menilai dana itu dapat digunakan untuk memasukkan ideologi politik, Eropa Timur menilai dana politik dapat mendistorsi proses elektoral, serta merusak demokrasi hingga alasan pihak asing mendanai itu, seperti di Rusia yang bertujuan untuk menguatkan Komunis internasionalnya (Komintern). ${ }^{7}$ Melihat sejarah ini, maka hal ini tidak menutup kemungkinan terjadi

\footnotetext{
${ }^{7}$ Lapinskas and Vogel, Opinion On The Prohibition Of Financial Contributions To Political Parties From Foreign, European Commission For Democracy Through Law (Venice Commision), Opinion Nomor 366/2009, hlm. 4.
} 
di Indonesia. Apalagi menurut keterangan peneliti Kemitraan Wahida Suhaib dalam salah satu koran Nasional Kompas, sudah ada indikasi para calon Pemilu Pilpres saat ini tahun 2014 lalu. ${ }^{8}$ Urgensi pelarangan ini jika dilihat dalam prespektif ekonomi politik sangat bertalian atu sama lain. Hal ini karena "sumbangan" dana kampanye pihak asing berpotensi besar terjadinya "lobby" kepentingan antara pihak asing dalam mengintervensi kebijakan politik di suatu negara. ${ }^{9}$ Suatu studi di berbagai belahan dunia menunjukkan bahwa sumbangan dana kampanye pemilu oleh pihak swasta penuh dengan syarat hubungan relevan bisnis dan politik sehingga dinilai dapat memberikan dampak negatif terhadap partai politik dan pemerintah. ${ }^{10}$

Dengan demikian, pengaturan Undang-undang Pemilu yang memperbolehkan dana pemilu dari pihak swasta atau perusahaan mestinya menjadi pertimbangan kembali bagi pembuat kebijakan. Pengaturan diperbolehkannya Peserta Pemilu dalam menerima sumbangan dana kampanye pemilu dari badan hukum swasta atau perusahaan, harusnya disinergiskan dan dikaitkan dengan pelarangan peserta pemilu terhadap sumbangan dana kampanye. Akibatnya, pelarangan tersebut, kontraproduktif dengan legalnya peserta pemilu menerima sumbangan dari pihak swasta, yang tiada lain juga mewakili kepentingan pihak asing di dalamnya.

\section{B. Dampak Keterlibatan Pihak Asing Sebagai Pemberi Sumbangan Dana Kampanye Pemilu Dalam Negara Hukum Pancasila Yang Demokratis}

Era Globalisasi saat ini, menuntut negara untuk lebih terbuka dengan dunia luar, baik dalam hubungan politik maupun dalam segi ekonomi. Bisa kita ihat berbagai perjanjian perdagangan maupun investasi dibuat sebagai bentuk dinamisnya suatu negara dengan hubungannya dengan negara luar. ${ }^{11}$ Sayangnya, hal ini tidak selalu menghasilkan dampak yang positif bagi suatu negara. Adakalanya justru Globalisasi justru dapat merusak tatanan kedaulatan suatu bangsa. ${ }^{2}$

8 Arimbi Ramadiani, Prabowo dan Jokowi Terima Sumbangan dari Pihak Asing, https://nasional.kompas.com/read/2014/07/18/13524601/Prabowo.dan.Jokowi.Diduga.Terima.S umbangan.dari.Pihak.Asing, diakses tanggal 15 Agustus 2018.

${ }^{9}$ OECD, Money In Politics: Sound Political Competition and Trust in Government, Working Paper OECD Policy Forum, Paris, 14-15 November 2013.

10 Shari Bryan and Denise Baer, Ed, Op. Cit., hlm. 19.

11 Shujiro Urata, Globalization and The Growth Free Trade Agreements, Asia Pasific Review Volume 9 No. 1 Tahun 2002, hlm. 20.

${ }^{12}$ Nicola Phillips, Globalisation and the "Paradox of State Power": Perspectives from Latin America, CSGR Working Paper No. 16/98 Tahun 1998, hlm. 4 
Hal ini tidak bisa dibayangkan jika pihak asing juga dapat mencampuri demokrasi dalam pemilu melalui sumbangan yang diberikannya kepada Peserta Pemilu. Adanya kelemahan dan celah hukum dalam pengaturan badan hukum swasta atau perusahaan yag notabene modalnya dimiliki asing, berdampak pada:

Pertama, Legalnya perusahaan dalam UU pemilu untuk memberikan sumbangan dana pemilu dapat menjadi jembatan pihak asing dalam melakukan tindakan transaksional terhadap peserta pemilu melalui perusahaan. Mengingat peserta pemilu adalah calon yang berkuasa nanti dalam suatu negara baik dalam esekutif maupun legislatif. Sumbangan tersebut akan jauh dari nilai tanpa "balas jasa", sehingga yang akan terjadi justu sebaliknya dimana antara pihak perusahaan dan peserta pemilu melalui istilah "sumbangan" menjadi hubungan yang transaksional. Pasalnya, Orientasi pihak asing, khususnya investor asing menanamkan modalnya adalah untuk mendapatkan keuntungan, (profit oriented) ${ }^{13}$. Akibatnya, sumbangan bantuan pihak asing memberikan ruang bagi kepentingan privat sector untuk dalam mengintervensi langsung kebijakan suatu negara. ${ }^{14}$ Jika yang terjadi demikian, maka proses pemilu yang ada sudah melukai demokrasi itu sendiri. Transaksi politik ini akhirnya penuh dengan syarat kepentingan privat sektor.

Hal ini tidak bisa dibayangkan jika sumbangan tersebut berubah menjadi ruang transaksional demi kepentingan privat sektor disana sehingga pemimpin yang lahir tidak akan mengakomodir setiap aspirasi masyarakat dalam mewujudkan negara yang demokratis, namun cenderung berpihak pada kepentingan pihak asing. Apalagi pihak asing sangat mendominasi investasi di Indonesia hampir di segala sektor strategis. Menurut Data Badan Koordinasi Penanaman Modal tahun 2018 PMA terdapat dalam sektor perkebunan sebesar 6,9 \%, Sektor Pertambangan 7.9\%, listrik, gas, dan air sebesar $10.5 \%$, property sebesar 23.1\%, Industri Logam dasar, Logal, Mesin sebesar 17.9\%, dan lainnya sebesar 33.7\%. Keseluruhan modal asing yang ada di Indonesia sebesar 58.8\%. Lantas pada saat undang-undang melegalkan perusahaan dalam memberikan sumbangan

\footnotetext{
13 Sentosa Sembiring, Hukum Investasi, Cetakan ketiga, Bandung: Nuansa Alia, hlm. 39.

14 Jefery K. Powel, Prohibition on Campaign Contribution From Foreign Source: Questioning Their justification in Global Interdependent Economy, University of Pennyslyvania Law School Journal, Volume 17 Nomor 3 Tahun 1999, hlm. 985-986.
} 
tersebut sama saja memberikan kesempatan bagi pihak swasta dan asing untuk melakukan "negosiasi" dengan peserta pemilu demi mencapai kepentingannya. Apalagi dalam pengaturan Peraturan Presiden Nomor 44 Tahun 2016 sendiri dimana misal usaha dibidang perkebunan mensyaratkan adanya modal asing sebesar 95\%. Sedangkan modal asing dalam sektor migas disyaratkan mulai dari 49\%-hingga $100 \%$ tergantung bentuk usahanya, sektor industri sebesar 49\%, sektor kesehatan $100 \%$, dan lain sebagainya.

Hampir semua sektor usaha yang ada di Indonesia terdapat modal asing di dalamnya dan mendominasi. Sumbangan dana pihak asing melalui perusahaan berpotensi sekali terjadinya transaksi kebijakan yang penuh kepentingan privat. ${ }^{15}$ Tingginya korupsi di Indonesia semakin menguatkan potensi terjadinya transaksi tersebut, sehingga kebijakan yang dibuat lebih mengutamakan kepentingan privat. $^{16}$

Legalnya keterlibatan pihak perusahaan dalam memberikan sumbangan dana kampanye, tanpa disadari memberikan celah terjadinya hubungan pihak asing dalam transaksional tersebut. Walaupun Undang-Undang Pemilu jelas memberikan pembatasan jumlah dana kampanye bagi perusahaan, namun Pasal inti sebagai ruang pihak asing maupun swasta itu masuk dalam Pasal 325 dan 329.

Otomatis, keberadaan hukum akhirnya digunakan untuk meletigimasi dominasi politik oleh pihak asing melalui legalitas sumbangan perusahaan terhadap dana kampanye pemilu. sumbangan tersebut bagian untuk memperkuat dominasi kepentingan ekonomi mereka nantinya. Dengan demikian, menurut penulis maka tidak cukup hanya pelarangan hanya dalam pihak asing saja dalam mendanai kampanye pemilu karena pihak asing juga bagian dalam perusahaan melalui modal yang ditanamkannya. Karena itu, kontektual legalitas keterlibatan pihak swasta sama berbahayanya dengan pelarangan pihak asing dalam sumbangan dana kampanye Pemilu.

Hubungan transaksional dalam dana kampanye melalui sumbangan yang diberikan oleh pihak asing maupun perusahaan sendiri berpotensi melukai kepentingan publik di dalamnya. ${ }^{17}$ Selama ini sudah banyak perusahaan swasta

\footnotetext{
15 Lynda W. Powell, The Influence of Campaign Contributions on Legislative Policy, A Journal of Applied Research in Contemporary Politics Volume 11, Issue No. 3 (October 2013), hlm. 6.

16 Inge Amundsen, Political Corruption: An Introduction to the Issues, Chr. Michelsen Institute Development Studies and Human Rights, 1999, hlm. 8.

${ }^{17}$ Shari, Op.Cit, hlm. 68.
} 
raksasa seperti Multinational Cooporation yang notabene berasal dari modal asing yang telah melukai hajat hidup orang banyak. Berbagai bentuk tindakan kesewenang-wenang perusahaan yang mengakibatkan masyarakat menjadi korban untuk kepentingannya. Hal itu dapat dilihat dalam berbagai kasus konflik agraria seperti pengusuran secara paksa terhadap masyarakat dalam suatu wilayah akan dijadikan lahan perkebunan, pertambangan, properti, dan sebagainya ${ }^{18}$ Sumbangan tersebut hanya dalam istilah semata, tetapi sumbangan tersebut dapat bekerja menjadi perampas hak masyarakat melalui kebijakan negara. Hal ini akhirnya jauh dari tujuan pemilu dalam melaksanakan prinsip kedaulatan rakyat itu sendiri. Hal ini yang menjadi ketakutan oleh Bapak Soekarno dan soepomo dalam sejarah konsitusi bangsa ini, ketika HAM diakui menjadi bagian dalam konstitusi maka hal itu dapat mengeser makna kedaulatan rakyat secara keseluruhan bukan rakyat secara perorangan semata. ${ }^{19}$ Akhirnya yang terjadi sebaliknya pemilu dilaksanakan dengan mengatasnamakan kedaulatan rakyat didalamnya.

Hasilnya, kebijakan negara tidak lagi mengutamakan kepentingan masyakat luas di dalamnya, namun kepentingan para pemodal, dalam hal ini privat sector. Padahal esensinya pemilu sebagai demokrasi politik, sangat berkaitan erat dengan demokrasi ekonomi. Ajang pemilu tidak dapat hanya diartikan bahwa rakyat memiliki kekuasaan tertinggi dalam politik ketika pemilu, melainkan rakyat juga harus memiliki kekuasaan tertinggi dalam ekonomi. ${ }^{20}$ Politik yang berdasarkan kedaulatan rakyat menghasilkan kebijakan ekonomi yang mengutamakan kepentingan rakyat didalamnya bukan justru kepentingan privat.

Sebab itu, masyarakat keseluruhan yang paling utama kepentingannya. Hal ini bagian yang tak terpisahkan dalam nilai-nilai Pancasila. Pengaturan segi pendanaan kampanye dalam undang-undang Pemilu sebaiknya merupakan manifestasi dari bentuk negara hukum pancasila yang demokratis, dimana prosesi pemilu diwujudkan dalam rangka untuk mencapai keadila sosial yang berkedaulatan rakyat. ${ }^{21}$ Dengan itu, intervensi asing sebagai privat party tidak akan

\footnotetext{
18 Mark Van Dorp, (2014), Multinationals and Conflict, International principles and guidelines for corporate responsibility in conflict-affected areas, Netherland: SOMO, hlm. 17.

19 Floriberta Aning (Penyunting), (2017), Lahirnya Pancasila, Cetakan Pertama, Yogyakarta: Media Presindo, hlm. 55.

20 Jimly Asshiddiqie, (2014), Konstitusi dan Konstitusionalisme Indonesia, Cetakan ke-3, Jakarta: Sinar Grafika, hlm. 112-124.

21 Tegu Prasetyo dan Ari Purnomosidi, (2014), Membangun Hukum Berdasarkan Pancasila,Bandung: Nusamedia, hlm. 48.
} 
mendapatkan celah dalam upayanya mendominasi politik dan ekonomi dalam keterlibatannya dalam pemilu, yang berpotensi melukai nilai fundamental bangsa ini.

Tentunya, peran hukum dalam pengaturan sumbangan dana pemilu baik dari pihak asing maupun perusahaan atau badan hukum swasta ini penting dalam membatasi hak demokrasi bagi perorangan yang berpotensi melukai esensi dari demokrasi yang berkedaulatan rakyat secara keseluruhan.

Kedua, Besarnya potensi pihak swasta dalam logika "bisnis-profit oriented" dalam hubungan transaksional ini, maka ini juga berdampak pada pola kampanye yang dilakukan oleh peserta pemilu. ${ }^{22}$ Tak jarang akhirnya mereka menghalalkan segala cara untuk memenangkan dalam konstetasi pemilu salah satunya melakukan "vote buyying" kepada pemilih. Adanya dukungan "sumbangan" tadi, bergeser menjadi "modal" dalam mendapatkan suara terbanyak. Pada prateknya, banyak pola vote buyying yang dapat dilakukan oleh Peserta Pemilu, seperti memberikan uang, sembako, pembuatan fasilitas umum, hingga pendanaan social project.

Rupa seperti ini membuat Pemilu hanya dijadikan media transaksi jual beli suara. Dampaknya, suara rakyat sebagai bentuk kedaulatan rakyat hanya menjadi "komoditas politik" ibaratnya dalam bisnis ekonomi. Padahal sejatinya, demokrasi tidak dapat dibeli dengan "uang". Alhasil pola ini yang merusak tatanan demokrasi bangsa Indonesia.

Ajang pemilu dengan melakukan pratik seperti itu secara tidak langsung merubah tatanan substansi pemilu menjadi transaksi perdagangan. Jual beli suara akhirnya menempatkan rakyat tidak lagi menjadi bagian dalam prose politik yang demokratis, melainkan ditempatkan menjadi benda mati atau barang. Secara tidak langsung pemilu seperti itu, mencerminkan sistem ekonomi yang kapitalistik. Padahal pemilu bukan ajang formil dalam memenuhi hak konsitusi rakyat dalam memilih pemimpin atau perwakilannya dalam sistem pemerintahan namun bagian dari proses pendidikan politik terhadap rakyat dalam suatu bangsa. Hadirnya istilah demokrasi, sejatinya bukan hanya menempatkan suara menjadi indikator keberhasilan keterlibatan rakyat dalam politik.

Jika demikian, maka demokrasi hanya ditempatkan sebagai cara untuk menciptakan kedaulatan rakyat. "Kedaulatan rakyat" disini mestinya dimaknai 
dengan komposisi yang justru sebagai tujuan. ${ }^{23}$ Demokrasi sebagai tujuan mengutamakan proses yang terus menerus, dengan lebih mengutamakan pendidikan politik bagi masyarakat. Vote buyying bukan pendidikan politik, namun semakin menguatkan konsepsi yang sangat kapitalistik.

Nyata bahwa kedua dampak di atas menunjukkan bahwa logika bisnis hari ini menjadi bagian yang tanpa disadari berdampak pada konsepsi demokrasi melalui pemilu. Hal ini penuh dengan syarat negara yang kapitalistik dan invidualistik. Padahal pembentukan negara Indonesia awalnya tidak berasal dari konsepsi negara liberal, akan tetapi pada perkembangannya justru pelan-pelan konsepsi liberal itu mengerus demokrasi kita.

Hal ini jelas, jauh dari nilai-nilai bangsa yang sudah disepakati sejak awal dibentuknya negara ini, dengan Nilai Pancasila yang menjadi dasar fundamental negara ini berdiri. Tentunya, demokrasi melalui pemilu jga harus diikuti dengan tatanan hukum yang menjaga nilai-nilai pancasila tersebut.

Intervensi asing dalam pemilu Kedua hal ini bertalian satu sama lainnya sebagaimana disebutkan bahwa "too much foreign interference in elections is a danger to a country's sovereignity." ${ }^{24}$ Dominasi politik justru alat yang paling penting dalam mempertahankan status quo. Seperti yang dikatakan oleh Lenin bahwa "negara adalah organ organ kekuasaan kelas, organ penindasan dari satu kelas terhadap kelas yang lain, ia adalah ciptaan "tata tertib" yang melegalkan dan mengekalkan penindasan ini dengan memoderasikan bentrokan antar kelas."25 Dominasi tidak harus dilihat dari kuantitas, namun bagaimana dominasi dapat mempengaruhi kebijakan negara lewat organ negara baik esekutif, legislatif, dan yudikatif. Dengan itu, jika pihak asing dapat mendominasi politik, maka kebijakan hukum suatu negara bertendensi pada pihak yang paling dominan. ${ }^{26}$

Tidak adanya sanksi mengenai pelarangan pihak asing terhadap dana kampanye hanya dikenakan kepada peserta pemilu sepertinya tidak berimbang. Dalam tindak pidana korupsi saja kedua pihak baik "suap maupun penyuap" samasama dikenakan sanksi. Dimana itu diatur dengan dengan jelas siapa Penyuap Aktif

\footnotetext{
${ }^{23}$ Adnan Buyung Nasution, (2006), Demokrasi Konstitusional, Jakarta: Kompas, hlm. 4.

24 Joo-Cheong Tam, Of Aliens, Money and Politics: Should Foreign Political Donation be banned?, King's Law Journal Volume 28 Nomor 2 Tahun 2017, hlm. 4.

${ }^{25}$ Lenin, State and Revolution, hlm. 7.

26 Lutfi J. Kurniawan dan Mustafa Lutfi, (2016), Hukum dan Kebijakan Publik, Cetakan Ke-2, Malang: Setara Press, hlm. 43.
} 
dan Penyuap Pasif. Jika dipersamakan dengan "sumbangan”, maka siapa yang "memberi", dan "menerima", maka mestinya sama-sama dikenakan sanksi. Tidak adanya aturan sanksi terhadap pihak asing sebagai pemberi tersebut, justu seolaholah "negara" melakukan pembiaran jika terjadi pendanaan dari pihak asing tersebut. Ketidaktegasan aturan Pasal 527 ini mestinya juga disertai sanksi terhadap pihak asing tersebut. Padahal jika melihat pada pengaturan sanksi secara filosofis, adalah wujud negara dalam mengatur wilayahnya, sebagaimana wujud kedaulatan nasionalnya. ${ }^{27}$ Sebagaimana disebutkan dalam asas teritorial dalam hukum pidana materil dimana siapapun yang melakukan tindak pidana di suatu wilayah negara, maka ia harus tunduk pada hukum wilayah tersebut. Walaupun pihak asing bukan warga negara Indonesia, namun tidak keistimewaan padanya untuk tidak tunduk dan patuh pada apa yang dilarang. ${ }^{28}$

Oleh karena it perlu ditambahkan klausul baru dalam Pasal 527 tersebut seperti dibawah ini yang dicantumkan pada pointer tersendiri misalkan dalam Pasal 527 ayat 1 huruf b "Bagi pihak asing yang memberi kepada peserta pemilu sebagaimana disebutkan dalam ayat 1 huruf a, maka dipidana dengan pidana yang sama sebagiamana disebutkan dalam ayat 1 huruf a,"

Hal ini mestinya dipertimbangkan lagi dalam pengaturan undang-undang pemilu ke depan. Besarnya kekuatan bisnis, yang hampir melibatkan pihak asing di Indonesia, bukan berarti negara memberikan keleluasaan atas tindak tanduknya, apalagi hingga mencampuri urusan politik atau kebijakan negara. Buruknya lagi, adanya bantuan pihak sumbangan oleh perusahaan atau pihak asing dalam pemilu, akan menambah daftar panjang tindakan koruptif di Indonesia. ${ }^{29}$ Bisa kita lihat kasus per kasus yang ada di Indonesia, Suap-Menyuap ataupun penyalahgunaan kewenangan, hampir semuanya berkaitan dengan kepentingan privat sektor di dalamnya, misal Kasus Buol, Kasus Bank Century, Kasus Pajak Gayus Tambunan, dan lainnya.

Hubungan yang "transaksional" tersebut berpotensi tidak berhenti setelah pemilu usai saja, namun pasca pemilu dan peserta pemilu yang telah menerima dana

27 Romli Atmasasmita, (2010), Hukum Pidana Internasional dalam Rangka Perdamaian dan Keamanan International, Jakarta: Fikahati Aneska, hlm. 116

${ }^{28}$ Andi Hamzah, (2008), Asas-Asas Hukum Pidana, Jakarta: Rineka Cipta, hal. 64.

29 Didik Supriyanto dan Lia Wulandari, (2012), Bantuan Keuangan Partai Politik, Metode Penetapan Besaran, Transparansi, dan Akuntabilitas Pengelolaan, Cetakan 1, Jakarta: Yayasan Perludem, hlm. 9 
dari pihak asing tadi harus memenuhi janjinya untuk melakukan deretan suapmenyuap dan penyalahgunaan kewenangan hingga akhirnya merugikan keuangan negara.

Sistematiknya dampak peran pihak asing dalam mendanai kampanye Pemilu, mestinya menjadi perhatian penuh pemerintah dalam pengaturan badan hukum swasta yang notabene juga bisa bagian dari pihak asing yang berasal dari investasi asing terkait sumbangan dana kampanye pemilu.

\section{PENUTUP}

\section{A. Simpulan}

Pelarangan peserta pemilu untuk menerima sumbangan dana kampanye dari pihak asing, sepertinya tidak selaras dengan Pembatasan Peserta pemilu untuk menerima sumbangan dana dari badan hukum swasta atau perusahaan. Namanya pembatasan bukan berarti tidak dibolehkan sama sekali. Legalnya badan hukum swasta dalam berkontribusi dalam dana kampanye pemilu dapat menjadi celah bagi pihak asing karena permodalan di berbagai usaha di Indonesia melibatkan pihak asing di dalamnya. Kategorisasi pihak asing dalam Peraturan KPU nomor 5 Tahun 2017 sendiri, salah satunya warga negara asing. Walaupun adanya pelarangan, pihak asing masih dapat terlibat melalui badan hukum swasta. Besarnya dominasi ekonomi pihak asing di Indonesia, tidak menutup kemungkinan pihak asing berusaha untuk mendominasi secara politik juga. Istilah sumbangan dapat berubah sebagai media transaksi kepentingan antara peserta pemilu dan pihak asing itu sendiri. Transaksi ini akan memberikan ruang bagi pihak asing untuk mengintervensi segala kebijakan negara demi kepentingannya. Akibatnya, Pihak asing tidak hanya mendominasi secara ekonomi, tetapi juga politik di Indonesia. Selain itu juga, pola transaksional ini juga berdampak pada cara peserta pemilu dalam mendapatkan suara pemilih. Akhirnya pemilu berubah menjadi hubungan perdagangan jual beli suara. Dampaknya suara hanya sebagai komoditas, bukan bagian dari demokrasi itu sendiri. Sistematiknya dampak ini, juga akan mempengaruhi watak peserta pemilu menjadi koruptif. "loby-loby" ini akan bersifat kontinuitas.

Adanya celah hukum pada istilah pihak asing dan pembatasan badan hukum swasta dalam pendanaan kampanye pemilu membuat pihak asing lebih leluasa dalam mengintervensi kebijakan negara demi kepentingan bisnisnya. Dengan 
demikian, maka perlunya penambahan klausul sanksi pidana terhadap "Pemberi dana dari Pihak Asing” kepada peserta pemilu. Ini perlu untuk mengantisipasi besarnya pengaruh pihak asing dalam kebijakan nasional melalui intervensi pada para peserta pemilu yang akan menduduki bagian kebijakan strategis negara pasca terpilih.

\section{DAFTAR PUSTAKA}

\section{Buku}

Adolf, Huala. (2014). Hukum Perdagangan Internasional. Jakarta: Raja Grafindo Persada.

Aning, Floriberta (Penyunting). (2017). Lahirnya Pancasila, Cetakan Pertama. Yogyakarta: Media Presindo

Asshiddiqie, Jimly. (2014). Konstitusi dan Konstitusionalisme Indonesia, Cetakan ke3. Jakarta: Sinar Grafika

Atmasasmita, Romli. (2010). Hukum Pidana Internasional dalam Rangka Perdamaian dan Keamanan International, Jakarta: Fikahati Aneska.

Dorp, Mark Van. (2014). Multinationals and Conflict, International principles and guidelines for corporate responsibility in conflict-affected areas. Netherland: SOMO.

Hamzah, Andi. (2008). Asas-Asas Hukum Pidana. Jakarta: Rineka Cipta.

Kurniawan, Lutfi J. dan Mustafa Lutfi. (2016). Hukum dan Kebijakan Publik, Cetakan Ke-2. Malang: Setara Press.

Lenin. State and Revolution.

Nasution, Adnan Buyung. (2006). Demokrasi Konstitusional. Jakarta: Kompas.

Sembiring, Sentosa Hukum Investasi, Cetakan ketiga, Bandung: Nuansa Ali.

Shari Bryan and Denise Baer, Ed, (2005). Money In Politics, A Study of Party Financing Pratices in 22 Countries. USA: Library of Congress.

Supriyanto, Didik dan Lia Wulandari. (2012). Bantuan Keuangan Partai Politik, Metode Penetapan Besaran, Transparansi, dan Akuntabilitas Pengelolaan,Cetakan 1. Jakarta: Yayasan Perludem.

Tegu Prasetyo dan Ari Purnomosidi. (2014). Membangun Hukum Berdasarkan Pancasila. Bandung: Nusamedia.

\section{Jurnal}

Soedjito, Bombong Bintoro. Peran Serta Swasta dalam Pembangunan Infrastruktur di Indonesia, Jurnal studi Pembangunan, Volume 1 Nomor 1 Tahun 1998.

Amundsen, Inge. Political Corruption: An Introduction to the Issues, Chr. Michelsen Institute Development Studies and Human Rights, 1999. 
Lapinskas and Vogel. Opinion On The Prohibition Of Financial Contributions To Political Parties From Foreign, European Commission For Democracy Through Law (Venice Commision). Opinion Nomor 366/2009.

OECD, Money In Politics: Sound Political Competition and Trust in Government. Working Paper OECD Policy Forum, Paris, 14-15 November 2013.

Powel, Jefery K. Prohibition on Campaign Contribution From Foreign Source: Questioning Their justification iin Global Interdependent Economy. University of Pennyslyvania Law School Journal, Volume 17 Nomor 3 Tahun 1999, h. 985-986.

Powell, Lynda W. The Influence of Campaign Contributions on Legislative Policy. A Journal of Applied Research in Contemporary Politics, Volume 11 Issue No. 3 (October 2013).

Urata, Shujiro. Globalization and The Growth Free Trade Agreements, Asia Pasific Review, Volume 9 No. 1 Tahun 2002.

Tam, Joo-Cheong. Of Aliens, Money and Politics: Should Foreign Political Donation be banned?. King's Law Journal, Volume 28 Nomor 2 Tahun 2017.

Phillips, Nicola. Globalisation and the "Paradox of State Power": Perspectives from Latin America. CSGR Working Paper No. 16/98 Tahun 1998.

\section{Laporan}

Badan Koordinasi Penanaman Modal. Laporan Realisasi Penanaman Modal PMDNPMA Tahun 2018

Badan Koordinasi Penanaman Modal, Siaran Pers Dorong Percepatan Penanaman Modal, BKPM Fokus Pada Konektivitas Ekonomi 2017.

\section{Media Online}

Ramadiani, Arimbi. Prabowo dan Jokowi Terima Sumbangan dari Pihak Asing. https://nasional.kompas.com/read/2014/07/18/13524601/Prabowo.dan. Jokowi.Diduga.Terima.Sumbangan.dari.Pihak.Asing. Diakses tanggal 15 Agustus 2018.

Kusuma, Hendra. Daftar Lengkap Paket Kebijakan Ekonomi I hingga XIV.

https://economy.okezone.com/read/2016/11/10/20/1538279/daftar-lengkappaket-kebijakan-ekonomi-i-hingga-xiv. Diakses tanggal 15 Agustus 2018.

\section{Peraturan Perundang-undangan}

Republik Indonesia, Undang-Undang Nomor 7 Tahun 2017 tentang Pemilihan Umum, Lembaran Negara Republik Indonesia Tahun 2017 Nomor 182.

Republik Indonesia, Undang-Undang Nomor 40 Tahun 2007 Tentang Perseroan Terbatas, Lembar Negara Republik Indonesia Tahun 2007 Nomor 106

Republik Indonesia Undang-Undang Nomor 25 Tahun 2007 tentang Penanaman modal, Lembar Negara Republik Indonesia Tahun 2007 Nomor 67 